\title{
Hyperkalaemia szívelégtelenségben. Új kezelési lehetőségek a láthatáron
}

\author{
Dékány Miklós, Vágány Dénes, Szabó Márta, Nyolczas Noémi, Kiss Róbert Gábor
}

\author{
MH EK, Kardiológiai Osztály, Budapest
}

Levelezési cím:

Dr. Dékány Miklós, 1134 Budapest, Róbert Károly krt. 44. E-mail: dekany.miklos@freemail.hu

\begin{abstract}
A csökkent bal kamrai ejekciós frakciójú szívelégtelenség gyógyszeres kezelésében az elmúlt 30 évben rendkívüli sikereket értünk el. A neurohormonális antagonisták irányelvek szerinti optimális alkalmazása mellett a mortalitás és a morbiditás drámai csökkenését lehetett elérni, hatásukban nemcsak a progresszív szívelégtelenség miatti halálozás, hanem az aritmiák okozta hirtelen halál veszélye is alacsonyabb lett.

Újabb felmérések szerint az elöbbi gyógyszerek alkalmazásának arányát illetőn nagyot léptünk elöre, miközben a napi klinikai gyakorlat során rendre a nagy kontrollált tanulmányokban alkalmazottnál, $s$ az irányelvekben javasoltnál alacsonyabb adagokban adjuk a gyógyszereket és emiatt kedvező hatásuk mértéke kérdéses.

Az ún. aluldozírozás számos oka közül az egyik a renin-angiotenzin-aldoszteron-rendszer gátlók (RAASi) hatásában gyakran fellépő hyperkalaemia. Különösen gyakori ez, amikor a szívelégtelenség csökkent vesefunkcióval, diabetes mellitusszal társul, és amikor a betegek elörehaladott korúak, vagyis amikor a megnövekedett rizikó miatt a legnagyobb szükség lenne hatékony neurohormonális antagonista kezelésre. A szérum káliumszint megemelkedése ritmuszavarok kiváltása révén fokozza a szívelégtelenségben már eleve magas hirtelen halál veszélyét.

A legutóbbi időkig olyan kezelésekkel, amelyek a RAASi-k optimális alkalmazása mellett is képesek lennének a kálium szérumszintjét, súlyos mellékhatások veszélye nélkül, tartósan normális tartományban tartani, nem rendelkeztünk.

Összefoglaló közleményünkben tárgyaljuk a hyperkalaemia epidemiológiáját, hatását a szívelégtelenség kimenetelére, befolyását a RAASi-kezelés alkalmazására. Foglalkozunk a hyperkalaemia megelőzésének módszereivel és tartós kezelésének újabb lehetőségeivel.
\end{abstract}

Kulcsszavak: csökkent ejekciós frakciójú szívelégtelenség (HFrEF), hyperkalaemia, renin-angiotenzin-aldoszteron-antagonista (RAASi) kezelés, patiromer, Na-cirkónium-cikloszilikát

\section{Hyperkalemia in heart failure. New treatments on the horizon}

In the pharmacological treatment of heart failure with reduced ejection fraction (HFrEF) extraordinary success was achieved in the last 30 years. With the optimal use of neurohormonal antagonists significant decrease in morbidity and mortality was reached. With the use of the optimal medical treatment, a decrease can be measured not only in the mortality caused by progressive heart failure, but also in the risk of the sudden cardiac death.

New studies show a substantial progress in the use of these medications, but they also indicate that these drugs are being used in lower doses compared to the guideline recommendations, so the rate of favourable effects of the treatment is questionable.

One among the multiple factors that may attribute to lower therapeutic doses is hyperkalemia during the use of renin-angiotensin-aldosterone system inhibitors (RAASi). It is particularly common in patients with renal failure, diabetes mellitus, in conditions which further necessitate the need of the effective neurohormonal antagonist treatment. The high serum potassium level further increases the risk of the malignant heart rhythm disturbances and sudden cardiac death, which is otherwise high in the HFrEF.

Until now there was no treatment to keep the potassium level in the normal range without serious side effects next to the optimal use of RAASi.

This review will discuss the epidemiology of hyperkalemia, its effect on the outcome of heart failure, and on the RAASi use. The opportunities of the prevention and the new possibilities of the long standing treatment of hyperkalemia will also be discussed.

Keywords: heart failure with reduced ejection fraction (HFrEF), hyperkalemia, renin-angiotensin-aldosterone antagonist (RAASi), patiromer, Na-zirkonium-cyclosylicate 


\section{Bevezetés}

A csökkent bal kamrai ejekciós frakciójú szívelégtelenségben (HFrEF) szenvedő betegek kezelése során a hyperkalaemia gyakori fellépése, a betegek optimális kezelését akadályozó, életkilátásaikat rontó, jelentős klinikai probléma. Hátterében elsősorban a vesén keresztüli csökkent káliumkiválasztás áll (1).

A béta-blokkolók mellett a renin-angiotenzin-aldoszteron-rendszer antagonistáinak (RAASi) alkalmazása HFrEF-ben a modern irányelvek szerint ún. első osztályú ajánlás (2). Bizonyítottan csökkentik a betegek össz- és kardiovaszkuláris halálozásának veszélyét, hospitalizációjuk gyakoriságát, s a szívelégtelenség klinikai súlyosságát. Fontos, hogy bár a neurohormonális antagonisták alkalmazásuk kezdetén átmenetileg ronthatják a vesefunkciót, a szívelégtelenséghez gyakran társuló krónikus veseelégtelenség progresszióját lassítják. Ugyanakkor, szerencsétlen módon, ezek a szerek fokozzák a hyperkalaemia rizikóját, különösen akkor, ha kombinációban alkalmazzuk őket. Egyes gyakori társbetegségek, mint a diabetes mellitus és a krónikus vesebetegség valamint a magas életkor ugyancsak fokozott veszélyt jelentenek.

A hyperkalaemia fellépése, de már a hyperkalaemiától való félelem is, a halálozást csökkentő gyógyszeres kezelések indokolatlan korai megszakítását, szuboptimális adagokban történő alkalmazását, s ez által a kardiovaszkuláris rizikó növekedését eredményezik.

Jelenleg a krónikus, rekurráló hyperkalaemia kezelésében csak korlátozott lehetőségekkel rendelkezünk. A RAASi-kezelés megszüntetése, vagy dózisuk nemegyszer jelentös csökkentése, a kacsdiuretikumok adagjának növelése, a káliumszegény diéta, vagy a nátrium-polisztirol-szulfonát (SPS) tartós alkalmazása közül egyik sem tekinthető optimálisnak, mivel túlélést javító gyógyszeres kezelések felfüggesztésével, vagy szuboptimális alkalmazásával, diétával kapcsolatos alacsony betegadherenciával, kedvezőtlen mellékhatás-profillal, illetve alacsony szintủ tolerábilitással járnak együtt (3).

Azonban hamarosan új, a gyomor és bélrendszerben káliumot megkötő, a szérum kálium (SeK) szintet hatékonyan és tartósan, súlyos mellékhatások nélkül csökkentő szerek kerülhetnek kezelési fegyvertárunkba. Az FDA és az Európai Gyógyszerhatóság (EMA) által már elfogadott patiromer (4), valamint a fejlesztés késői stádiumában lévő, s az EMA felé pozitív ajánlással rendelkező nátrium-cirkónium-cikloszilikát (ZS-9) (5) a jelenlegi krónikus hyperkalaemia kezelési lehetőségekhez képest lényegesen előnyösebbeknek tünnek, s lehetővé tehetik a RAASi-kezelés fenntartását, optimális alkalmazását, sőt kiterjesztését is magas hyperkalaemia rizikójú HFrEF betegek csoportjára.

\section{A hyperkalaemia definíciója, következményei és o̊sszefüggése a betegek halálozásával}

Hyperkalaemiáról $5 \mathrm{mmol} / \mathrm{l}$ feletti SeK-szint esetén beszélünk, és elkülönítünk enyhe $(5,0-5,5 \mathrm{mmol} / \mathrm{l})$, mérsékelt $(5,5-6,0 \mathrm{mmol} / \mathrm{l})$ és súlyos hyperkalaemiát $(>6$ $\mathrm{mmol} / \mathrm{l})$. A magas rizikójú betegeknél a SeK-szint gyorsan és váratlanul emelkedhet és a hyperkalaemia gyakran visszatér.

A SeK normális értékének fontos szerepe van a szívizom nyugalmi membránpotenciáljának fenntartásában. A kálium 98\%-ban az intracellularis térben helyezkedik el. Megemelkedett szintje a szérumban csökkenti az intracelluláris-extracelluláris káliumarányt és a sejtmembrán részleges depolarizációját, legsúlyosabb esetekben az akciós potenciál szétesését okozza. A jellemző EKG-eltérések - bár nem szorosan függnek össze a SeK szintjével - súlyossági sorrendben a következők: magas, csúcsos T-hullámok megjelenése, a QT-távolság lerövidülése, a P-hullám eltúnése, a QRS-komplexus kiszélesedése, végül kamrafibrilláció vagy hullámok nélküli preterminális ritmus kialakulása. A súlyos ingerületvezetési zavarok és a kamrafibrilláció legtöbbször hirtelen halált eredményeznek.

A SeK-szint és a halálozás összefüggését a közelmúltban több felmérésben vizsgálták. Aldahl és munkatársai (6) a dán nemzeti regiszterből kiválasztott 19549 kacsdiuretikum és angiotenzin konvertáz enzim gátló (ACEi)/angiotenzinreceptor-blokkoló (ARB) kezelésben részesülö krónikus szívelégtelen beteg esetében értékelték a SeK-szint és a halálozás öszszefüggését. A betegeket a SeK-szint mérése után 90 napig követték. A halálozás rizikóját többváltozós Cox proporcionális hazard modell alkalmazásával értékelve azt észlelték, hogy a 4,2-4,4 mmol/l-es SeK-szintet referenciának tekintve, a halálozás veszélye mind az alacsonyabb, mind a magasabb SeK-szintek mellett szignifikáns mértékben emelkedett. Ami a magasabb SeK-szintek veszélyét illeti, már enyhe SeK-szint emelkedéskor (5,1-5,5 mmol/l) magasabb kockázatot észleltek: HR: 1,6 (Cl: 1,29-1,97), míg az 5,6-7,4 $\mathrm{mmol} / \mathrm{l}$ SeK-tartományban a halálozás kockázatának aránya több mint háromszorosnak bizonyult: HR: 3,31 (Cl: 2,61-4,20).

Az előbbi adatok riasztó voltát tompíthatja, és egyben felhívhatja a figyelmet a mineralokortikoid-receptor-antagonista (MRA) kezelés jelentőségére, hogy spironolakton alkalmazása esetén mérsékelt hyperkalaemia $(5,0-5,5 \mathrm{mmol} / \mathrm{l})$ ellenére is kedvezőbb volt a betegek mortalitása, mint a placebóval kezelt normális SeK-szintü betegeké (7). Ennek a megfigyelésnek felel meg az ESC 2016-os ajánlása (2), amely szerint csak $5,5 \mathrm{mmol} / \mathrm{l}$-es SeK-szint felett javasolt megfelezni az MRA adagját, és a szer elhagyása csak 6,0 mmol//-nél magasabb SeK-érték esetén ajánlott. 


\section{A hyperkalaemia gyakorisága RAASi-kezelés mellett}

A mérföldkövet jelentő RAASi-tanulmányokból a hyperkalaemia magas rizikójával járó, jelentősen károsodott vesefunkciójú és az 5,0 mmol// feletti SeK-szintü betegeket kizárták. Idős betegek csak kis számban voltak képviselve a vizsgálatokban. Mindezek ellenére, akkor, amikor kombinációban alkalmazták a RAASi-ket magas arányban lehetett megemelkedett SeK-szinteket észlelni. A SOLVD treatment tanulmányban (8), ahol csak egy RAASi-t, az enalaprilt alkalmazták az $5,5 \mathrm{mmol} / \mathrm{l}$ feletti SeKszint az enalaprillal kezelt csoportban $7,8 \%$, míg a kontrollcsoportban $4,2 \%$ gyakoriságúnak bizonyult. Ezzel szemben az ACEi és MRA kombinált kezelést alkalmazó tanulmányokban jelentősen nagyobb SeK-szint különbségeket észleltek. A RALES-vizsgálatban (9) spironolakton hatásban 19\%-ban volt $5,5 \mathrm{mmol} / \mathrm{l}$ feletti a SeK-szint, szemben a kontrollcsoportban észlelt 5,6\%-os értékkel. Ugyanezek az EMPHASIS-HF (10) tanulmányban 11,8 vs. $7,8 \%$-nak bizonyultak. Említést érdemel, hogy a PARADIGMHF-tanulmányban (11) a sacubitril-valsartan hatásban az $5,5 \mathrm{mmol} / \mathrm{l}$ feletti SeK-szintủ betegek aránya ugyancsak magas, $16,1 \%$ volt. Az elöbbi megfigyelések azt mutatják, hogy abban az esetben, ha HFrEF-ben kombinált RAASi-kezelést alkalmazunk, a klinikailag jelentős hyperkalaemia rizikójának két-háromszoros növekedését lehet megfigyelni.

Számos populációs tanulmány hívta fel a figyelmet arra, hogy a hyperkalaemia veszélye akkor, amikor nem szelektált, nem szorosan követett beteg populációkban alkalmazzák az MRA-kezelést, jelentősen magasabb lehet. A vészharangot elöször Juurlink és munkatársai vizsgálatának eredménye húzta meg (12). 1300000 65 évesnél idősebb, spironolaktonnal kezelt beteg adataiból az derült ki, hogy a RALES-tanulmány közlését megelőző időszakban észlelthez képest mind a hyperkalaemia miatti hospitalizáció, mind a hyperkalaemia miatti halálozás háromszorosára növekedett. Ez lehet a magyarázata annak, az ugyancsak ebben a tanulmányban tett megfigyelésnek, amely szerint a RALES-tanulmányt követően alkalmazott spironolakton kezelés nem csökkentette a szívelégtelen betegek halálozását. Későbbi populációs vizsgálatok megerősítették Juurlink adatait $(13,14)$, amelyek a megfelelő betegszelekció és kontroll nélküli, sokszor a kontrollált tanulmányokban alkalmazottnál nagyobb dózisú MRA-kezelés veszélyességét bizonyították.

Mindezek alapján megállapíthatjuk, hogy a napi klinikai gyakorlatban a hyperkalaemia gyakori elektrolitzavar. Gyakorisága a magas rizikójú szívelégtelen betegek körében, amikor a SeK-szint elöírásszerü ellenőrzése gyakran elmarad, elérheti a 30\%-ot, vagy, mert kimutatására közel sem mindig kerül sor, még magasabb gyakoriságú is lehet.

\section{A SeK-szint és a RAASi-kezelés összefüggései}

A szívelégtelenség gyógyszeres kezelésének notórius problémája az irányelvek ajánlásával szembeni alacsony gyógyszeradagok, köztük RAASi-dózisok alkalmazása. A több mint 12000 beteg adatait elemző ESC Heart Failure Long-Term Registry szerint a betegek $67-92 \%$ ában alkalmazták a javasolt RAASi-szereket, miközben csak mintegy 30\%-ukban történt meg a céldózisig feltitrálás (15). Egy nagy USA-adatbázis (16) adatainak (>205 000 beteg) elemzéséből az derült ki, hogy a RAASi-k céldózisán lévő betegek közül hyperkalaemia miatt megszakították a kezelést a betegek 26\%-ban, s tartósan csökkentették az elöbbi szerek dózisát 21\%ban. A kezelés megszakítására, illetve az alacsonyabb adagok alkalmazására már enyhe SeK-szint-emelkedés (5,1-5,4 mmol/l) esetén is sor került.

Két újabb európai felmérés eredményei is kimutatták a RAASi-k alacsony adagban történő alkalmazásának gyakorlatát és ennek kedvezőtlen hatását a HFrEF-betegek életkilátásaira $(17,18)$.

\section{A hyperkalaemia megelőzésének stratégiái}

A hyperkalaemia megelőzési stratégiái közül a legfontosabbaknak a megfelelő beteg szelekciót, a káliumbevitel kontrollálását, egyes nem kardiovaszkuláris gyógyszerek alkalmazásának mellőzését, a betegek rendszeres követését, vesefunkciójuk és SeK-szintjük irányelvek szerinti ellenőrzését tekinthetjük.

\section{Betegszelekció}

Idős, diabéteszes, csökkent vesefunkciójú, emelkedett SeK-szintü ( $\geq 5,0 \mathrm{mmol} / \mathrm{l})$ szívelégtelen betegeknél kombinált RAAS-blokád alkalmazásakor a hyperkalaemia veszélye miatt különösen gondosan kell eljárnunk: szoros laboratóriumi kontroll mellett fokozatosabb dózistitrálást kell alkalmazni (19). Figyelemre méltó különbség a legújabb európai (2) és amerikai (ACC/AHA) szívelégtelenség irányelv (20) között, hogy míg az utóbbi az MRA-kezelést csak akkor tartja megengedhetőnek, ha a szérum kreatininszintje férfiak esetében $<221 \mu \mathrm{mol} / \mathrm{l}$, nők esetében $<170 \mu \mathrm{mol} / \mathrm{l}$, vagy mindkét nemben az eGFR $>30 \mathrm{ml} /$ perc/1,73 $\mathrm{m}^{2}$, valamint a SeK $<5 \mathrm{mmol} / \mathrm{l}$, addig az új európai irányelv nem határoz meg számszerü, kontraindikációt jelentő, korlátozó értékeket, hanem megengedőbb; óvatosságra, specialistához fordulás szükségességére, szoros laboratóriumi kontrollokra és a kedvezőtlen gyógyszer-interakciók számba vételére hívja fel a figyelmet (21). Az európai ajánlás a kombinált RAASi-kezelések felfüggesztését csak $>6 \mathrm{mmol} / \mathrm{l}$ SeK-szintnél és $>310 \mu \mathrm{mol} / /$ szérum kreatininszintnél, illetve $<20 \mathrm{ml} / \mathrm{perc} / 1,73 \mathrm{~m}^{2}$ eGFR-szintnél tartja szükségesnek. Rövid távú felfüggesztést és a RAASi-kezelés visszaállításának mielőbbi megkísérlését javasolja. 
A kezelés limitációt illető liberálisabb felfogás tükrözi azt a felismerést, hogy egy magas rizikójú szívelégtelen beteg esetében az ún. I. osztályú ajánlással rendelkező halálozást csökkentő gyógyszeres kezelések tartós megszüntetése a kórkép kimenetelét negatívan befolyásoló végzetes döntés lehet.

\begin{abstract}
A káliumbevitel kontrollálása
Magas rizikójú betegeknél a táplálékkal bevitt kálium mennyiségének korlátozása fontos szerepet játszhat a hyperkalaemia veszélyének csökkentésében. Ebben a vonatkozásban a betegek rendszeres oktatása, diétás tanácsokkal ellátása sokszor elmarad, vagy elégtelen. Törekedni kell arra, hogy a napi káliumbevitel ne haladja meg a 2-3 g-ot. Különösen veszélyes lehet, ha a betegek nátriumot helyettesítő magas arányban kálium-kloridot tartalmazó sókészítményeket használnak (22). A magas káliumtartalmú táplálékok széles körének elkerülése érdekében diétás útmutatókkal javasolt ellátni a betegeket. (Ezeknek az útmutatóknak természetesen figyelmeztetni kell a betegeket a nátrium bevitel csökkentésének fontosságára is.)
\end{abstract}

\section{A hyperkalaemia ősszefüggése egyes nem kardiovaszkuláris indikációból alkalmazott gyógyszerekkel}

A hyperkalaemia veszélyének csökkentéséhez számos nem kardiovaszkuláris indikációból alkalmazott gyógyszer mellőzése szükséges. Ide tartoznak a vesén keresztüli káliumkiválasztást különböző mechanizmusok révén csökkentő non-szteroid gyulladásgátlók (NSAID-ok), köztük a szelektív ciklooxigenáz-gátlók. Egyes társszakmák képviselöi nem egyszer nincsenek tekintettel a hyperkalaemia veszélyére és ezeknek a szereknek a tartós alkalmazását javasolják.

Annak ellenére, hogy kockázatos voltát már évek óta kimutatták, még a kardiológusok körében is kevésbé ismert a trimethoprim/sulfamethoxazol veszélye. Spironolaktonnal is kezelt 66 évesnél idősebb betegeket 12,4-szer gyakrabban kellett hyperkalaemia miatt hospitalizálni az amoxicillinnel kezeltekhez képest, ha trimethoprim/sulfamethoxazol kezelésben részesültek $(23,24,25)$. Ugyancsak kerülni kell egyes CYP3A4-gátló szereket, így az azol típusú gombaellenes készítményeket, például a ketokonazolt. Figyelembe kell venni, hogy a heparin tartós adása, az aldoszteron-produkció gátlása révén, ugyancsak hyperkalaemiát okozhat.

Értelemszerü, hogy a RAASi-k kombinációjával kezelt betegeknél az úgynevezett kálium-spóroló diuretikumok, az amilorid és a triamteren valamint a gyógyszertárakban nem egyszer javasolt furosemid melletti káliumpótlás kerülendők. Ha kacsdiuretikum kezelés mellett alacsony SeK-szintet észlelünk, ne káliumpótlást alkalmazzunk, hanem kíséreljük meg az MRA adagjának növelését.

\section{Optimális monitorozási stratégiák} alkalmazása

Az ez irányú ajánlások betartása a hyperkalaemia elkerüléséhez elengedhetetlenek. A megfelelő SeK-szint-monitorozás rendszerint csak szívelégtelenség gondozási programok, szívelégtelenség ambulanciák keretében történik meg, a napi klinikai gyakorlatban sokszor elmarad. Mind az európai irányelv (2) mind az amerikai irányelv (19) részletesen foglalkozik a monitorozás szabályaival. A RAASi-kezelések bevezetésekor, dózisuk változtatásakor, romló vesefunkció esetén, interkurrens, hipotóniához, csökkenő veseperfúzióhoz vezető betegségek fellépésekor, például folyadékvesztéssel járó gasztrointesztinális infekciók esetén, kiemelt jelentőségủ a SeK-szint szoros ellenőrzése.

\section{A hyperkalaemia tartós kezelésének jelenlegi lehetőségei}

A krónikus rekurráló hyperkalaemia veszélyét jelenleg a kacsdiuretikumok dózisának növelésével, a RAASi-k adagjának csökkentésével, vagy a kombinációban történő alkalmazásuk megszüntetésével, végső esetben elhagyásukkal, nagyfokú vesefunkció-romlás esetén, tartós hemodialízis alkalmazásával csökkenthetjük (26). Ezeknek az eljárásoknak az előnytelen és körülményes volta közismert.

Nem egyszer megkísérlik a nátrium-polisztirol-szulfonát (resonium, SPS) tartós alkalmazását is (1. táblázat). Kérdéses hatékonysága, gyakori, sokszor súlyos gasztrointesztinális mellékhatásai (pl. bélnekrózis), folyadékretenciót növelő hatása miatt tartós adása szívelégtelenségben nem javasolt. Mivel alacsony káliumszelektivitású, hatásában jelentős hypomagnesaemia és hipokalcémia is kialakulhat. Az SPS-t, gyakori mellékhatásának a székrekedésnek a megszüntetését célozva, korábban hashajtó készítményekkel, például szorbitollal alkalmazták együtt. Az FDA a súlyos gasztrointesztinális mellékhatások (pl. bélnekrózis) miatt, ezt az együttadást megtiltotta.

\section{Új, alacsonyabb hyperkalaemia veszéllyel járó gyógyszeres kezelések}

Bizonyos szintű rizikócsökkentésre újabb szívelégtelenség gyógyszerek alkalmazásától is számíthatunk. Ha enalapril helyett sacubitril/valsartant, LCZ696-ot tudunk alkalmazni, a hyperkalaemia rizikója alacsonyabb lehet (27). Előzetes adatok alapján $(28,29)$ akkor is kisebb lehet a rizikó, ha az új, szelektív, nem szteroid struktúrájú MRA, finerenon bekerülhet terápiás fegyvertárunkba. Erre a most folyó klinikai végpontú kontrollált tanulmányok pozitív eredményei esetén kerülhet sor. 
1. TÁBLÁZAT. A bélrendszerben káliumot megkötő szerek jellemzői

\begin{tabular}{|c|c|c|c|}
\hline & $\begin{array}{l}\text { Nátrium-polisztirol- } \\
\text { szulfonát }\end{array}$ & Patiromer & $\begin{array}{l}\text { Nátrium-cirkónium- } \\
\text { cikloszilikát }\end{array}$ \\
\hline Hatásmechanizmus & $\begin{array}{l}\text { Nem specifikus káliumkötés és } \\
\text { nátriumra cserélés }\end{array}$ & $\begin{array}{l}\text { Nem specifikus káliumkötés és } \\
\text { kalciumra cserélés }\end{array}$ & $\begin{array}{l}\text { Szelektív káliumkötés és nátrium- } \\
\text { ra és hidrogénre cserélés }\end{array}$ \\
\hline $\begin{array}{l}\text { Normokalaemia eléréséig } \\
\text { eltelt idő }\end{array}$ & $\begin{array}{l}\text { Nem ismert, változó } \\
\text { hatékonyság }\end{array}$ & 1 héten belül & A betegek $84 \%$-ánál 24 órán belül \\
\hline Hatás fellépéséig eltelt idő & Változó (órákig tarthat) & $\begin{array}{l}7 \text { órával az első dózist köve- } \\
\text { tően szignifikáns SeK-szint } \\
\text { csökkenés }\end{array}$ & $\begin{array}{l}\text { Átlag 2,2 óra a SeK normalizáló- } \\
\text { dásáig eltelt idő (1 órán belül } \\
\text { kezdődő hatás) }\end{array}$ \\
\hline Gyógyszerkölcsönhatás & $\begin{array}{l}\text { Antacidumok, laxativumok, } \\
\text { digitalis, sorbitol, lithium, } \\
\text { thyroxin }\end{array}$ & $\begin{array}{l}\text { A többi orális gyógyszert csak } \\
3 \text { órával elötte vagy utána lehet } \\
\text { alkalmazni }\end{array}$ & $\begin{array}{l}\text { Nincs klinikailag jelentős } \\
\text { gyógyszerkölcsönhatás }\end{array}$ \\
\hline Káliummegkötés helye & Vastagbél & A vastagbél disztális szakasza & $\begin{array}{l}\text { Mind a felső, mind az alsó } \\
\text { gasztrointesztinális }(\mathrm{Gl}) \text { régió } \\
\text { (nem bizonyított) }\end{array}$ \\
\hline $\begin{array}{l}\text { Biztonságosság/ } \\
\text { tolerálhatóság }\end{array}$ & $\begin{array}{l}\text { Rossz tolerálhatóság } \\
\text { Hypokalaemia és más elektro- } \\
\text { litzavarok. Hányinger, hányás, } \\
\text { hasmenés, székrekedés. } \\
\text { Bélnekrózis! }\end{array}$ & $\begin{array}{l}\text { Jó tolerálhatóság. } \\
\text { Hypokalaemia, hypomagnesa- } \\
\text { emia. Ritkábban hányinger, há- } \\
\text { nyás, hasmenés, székrekedés. }\end{array}$ & $\begin{array}{l}\text { Jó tolerálhatóság } \\
\text { Hypokalaemia, ödéma, hipertóni- } \\
\text { ásoknál vérnyomás-emelkedés. } \\
\text { Ritkábban hányinger, hányás, } \\
\text { hasmenés, székrekedés. }\end{array}$ \\
\hline $\begin{array}{l}\text { Forgalomba hozatali } \\
\text { engedély }\end{array}$ & $\begin{array}{l}\text { USA } 1958 \\
\text { EU } 1980\end{array}$ & $\begin{array}{l}\text { USA } 2015 \\
\text { EU } 2017\end{array}$ & $\begin{array}{l}\text { USA folyamatban } \\
\text { EU folyamatban }\end{array}$ \\
\hline
\end{tabular}

\section{A hyperkalaemia krónikus kezelése káliumot a gyomor-bél rendszerben megkötő́ újabb szerekkel}

\section{Patiromer (1. táblázat)}

A patiromer mind az FDA-tól, mind az EMA-tól forgalomba hozatali engedéllyel bíró szer, amely egy nem felszívódó kation-cserélő polimer. Előnye az SPS-sel szemben, hogy folyadékkal érintkezve nem duzzad meg és ez által kisebb a gasztrointesztinális mellékhatások veszélye. További előnyt jelent nagyfokú kálium-szelektivitása, valamint az, hogy mivel nem nátriumot, hanem kalciumot cserél káliumra, nem okoz nátriumterhelést, amely sajátsága szívelégtelen betegek esetében különösen fontos. Hatásában a SeK-szint átlag 7 óra után kezd csökkenni, maximális hatásának elérése egyhetes alkalmazása után várható (1. táblázat). Hátránya, hogy csak por alakban áll rendelkezésre és csak szuszpenzió formájában alkalmazható.

A patiromerrel végzett tanulmányok közül a PEARL-HFben 105 MRA indikációval bíró olyan szívelégtelen beteget vizsgáltak (30), akiknél korábban hyperkalaemia miatt meg kellett szakítani a RAASi-kezelést vagy az eGFR $<60 \mathrm{ml} /$ perc $/ 1,73 \mathrm{~m}^{2}$ volt. A betegek random módon napi $30 \mathrm{mg}$ patiromert, vagy placebót kaptak. A spironolakton napi $25 \mathrm{mg}$-os adagját akkor növelték 50 $\mathrm{mg}$-ra, ha a 25 . napon a SeK $\leq 5,1 \mathrm{mmol} / \mathrm{l}$ volt. A tanulmány végén a patiromerrel kezeltek SeK-szintje szignifikánsan alacsonyabbnak bizonyult és közülük lényegesen nagyobb arányú volt a napi $50 \mathrm{mg}$ spironolaktont toleráló betegek aránya.

Egy újabb tanulmányban, az OPAL-HK-ban (31) 237 harmadik vagy súlyosabb stádiumú veseelégtelenség- ben szenvedő, hyperkalaemiás (SeK 5,1-6,5 mmol/l), RAASi-kal kezelt beteget vontak be. Közülük 102-nek $(42 \%)$ szívelégtelensége is volt. 4,2 vagy $8,4 \mathrm{~g} / \mathrm{nap}$ patiromer kezelés mellett az első 4 hétben a betegek 76\%-ában a SeK-szint normalizálódott. Ezt követően 8 hétig random módon vagy folytatták a patiromer kezelést vagy csak placebót alkalmaztak. A patiromerrel kezelteknél a rekurrens hyperkalaemia szignifikánsan alacsonyabb arányban fordult elő (8\%), mint a placebóval kezelteknél (52\%). A 102 szívelégtelen beteg alcsoportjának vizsgálata a tanulmány egészében észlelthez hasonló kedvező patiromer hatást és mellékhatás arányt mutatott.

Bakris és munkatársai hipertóniás, diabéteszes nephropathiás, hyperkalaemiás, RAASi-kezelésben részesülő betegeknél az AMETHYST-DN-vizsgálatban (32) azt észlelték, hogy 4 hetes, különböző dózisú patiromer kezelés mellett, az enyhe (SeK: 5,0-5,5 mmol/l) és közepesen súlyos (SeK: 5,5-5,9 mmol/l) hyperkalaemiások SeK-szintje normalizálódott. Patiromer hatásában a vizsgálat további 48 hete alatt, folytatva a RAASi-kezelést is, normális SeK-szintet lehetett fenntartani. Fontos, hogy a patiromer kezelés abbahagyását követően már a 2. napon a SeK-szint jelentős emelkedése volt megfigyelhető.

A patiromer kezelés során figyelembe kell vennünk, hogy a szer egy sor gyógyszer felszívódását is gátolja, s ezért alkalmazásukra csak a patiromer bevételét megelőző 3 órás időszak előtt, illetve után kerülhet sor (33).

Mellékhatásokként gasztrointesztinális szimptómák: hasmenés, hányinger, hányás alacsony gyakoriságú elöfordulását észlelték. Az OPAL-HK-tanulmányban ezek a 
mellékhatások a betegek 4\%-ában jelentkeztek. A hypomagnesaemia, valamint hypokalaemia legtöbbször a kezelés elején fellépő, korrigálandó mellékhatások.

Klinikailag releváns megfigyelésnek tekinthető, hogy patiromer hatásában az aldoszteronszint és a hipertóniás betegek vérnyomása is csökkent (34).

\section{Nátrium-cirkónium-cikloszilikát (ZS-9) \\ (1. táblázat)}

A ZS-9 egy szagtalan, íztelen, por formájú, anorganikus vegyület, amelyet szuszpenzió formájában a táplálékkal együtt javasolt bevenni. Folyadékkal érintkezve térfogata nem nő. Növelheti a betegek adherenciáját, hogy tabletta formájában is rendelkezésre áll. Nagyfokban káliumszelektív. A káliummegkötő sajátsága az egész gyomor-bél rendszerben és nemcsak a vastagbél disztális szakaszában érvényesül. Hatása gyorsan, pár órán belül kialakul. Szívelégtelen betegek esetében figyelembe kell venni, hogy mivel nátriumot cserél káliumra, bizonyos szintü nátriumterhelést, ödémaképződést, folyadékretenciót okozhat. A patiromerrel szemben előnye, hogy más gyógyszerekkel nincs kölcsönhatása.

A ZS-9-cel eddig végzett vizsgálatokat krónikus veseelégtelen, RAASi-kezelésben részesült betegeken végezték.

A két rövidtávú (ZS-002 és ZS-003) vizsgálat közül aZ utóbbiban a szívelégtelenek aránya 42\%, a HARMONIZE (ZS-004) vizsgálatban 36\% volt. A ZS-003 és a ZS-004 vizsgálatban 48 órás nyílt, iniciális fázis után randomizált, placebokontrollált vizsgálati fázis következett, amelyben az ZS-9 különböző dózisait alkalmazták $(35,36)$. Az összes vizsgálatban a betegek döntő hányadában gyorsan csökkenő, normális tartományú SeK-szintet lehetett elérni úgyis, hogy a bevezető 48 órás fázis után a betegek a ZS-9-et csak naponta egyszer kapták.

Jelenleg egy 12 hónapos, nyílt, a szer biztonságosságát vizsgáló tanulmány van folyamatban (ZS-005). Hipertóniás, RAASi-kezelésben részesülő 746 betegnél, napi 5 g ZS-9-et alkalmazva, az eddigiek szerint tartósan normális SeK-szintet lehet fenntartani. A szer hosszú távon is jól tolerálhatónak bizonyult, a székrekedés 5\%-os, a perifériás ödéma 7,6\%-os gyakorisága tekinthető említésre méltó mellékhatásnak. A ZS-005 vizsgálat kezdeti eredményeit Anker és munkatársai az ESC 2016-os kongresszusán poszter formájában mutatták be.

A placebóval kontrollált vizsgálatokban, például a HARMONIZE-tanulmányban (ZS-004), csak a legnagyobb napi 15 g-os ZS-9 dózis melletti ödéma képződés $14,3 \%$-os és a hypokalaemia $10,3 \%$-os aránya volt jelentős. Ugyanebben a tanulmányban napi $5 \mathrm{~g}$ ZS-9 hatásában ezek a mellékhatások nem, vagy csak minimális gyakorisággal fordultak elö.

Általánosságban elmondható, hogy a SeK-szint-csökkenés mértéke annál nagyobbnak bizonyult, minél magasabb volt a kezelt populáció kiindulási SeK-szintje és minél nagyobb dózisban alkalmazták a ZS-9-et. Ebben a vonatkozásban fontos megjegyezni, hogy a szer közepes, napi 5 g-os adagjai is hatékonynak bizonyultak. A szívelégtelen betegek alcsoportjában (94 beteg a HARMONIZE-tanulmányból) a ZS-9 hatását külön elemezve, azt észlelték, hogy mind a napi 5, 10 és $15 \mathrm{~g}$-os adag hatásosan csökkentette, majd normális szinten tudta tartani a RAASi-kezelésben is részesülő betegek SeK-szintjét. A szer alkalmazása ebben a betegcsoportban is biztonságos volt (37). Mindezek mellett érdemes figyelembe venni, hogy a magas rizikójú, szívelégtelenség miatt hospitalizált, vagy malignus ritmuszavar miatt kezelt, valamint a krónikusan hemodializált betegeket kizárták az előbbi tanulmányokból.

\section{Evidenciálk által válasz nélkưl hagyott kérdések - Perspektívák}

A szívelégtelenségben, a krónikus vesebetegségben, a diabéteszben szenvedők, valamint az idős betegek növekvő száma miatt, akiknél RAASi-kezelés indokolt, a hyperkalaemia egyre jelentősebb klinikai probléma lesz. A RAASi-kezelés felfüggesztése, dózis csökkentése nemkívánatos válasznak tekinthető a problémára. Mivel a nagy kontrollált tanulmányokban a magas hyperkalaemia rizikónak kitett betegek, az elörehaladott vesebetegségben szenvedők, valamint az idős betegek nincsenek reprezentálva, a szívelégtelenség gyógyszeres kezelésében jelenleg egy nagy betegcsoportot érintő kritikus evidenciahiánnyal állunk szemben (26). Az evidenciahiány által érintett betegek jelentős hányada válhatna kezelhetővé, ha a hyperkalaemia veszélyét tartósan, súlyos mellékhatások nélkül képesek lennénk csökkenteni. A két újabb, a gyomor-bél rendszerben káliumot megkötő szer, a patiromer és a ZS-9 megfelelhet ennek az elvárásnak. Alkalmazásuk révén eddig nem, vagy csak szuboptimálisan kezelhető betegek válhatnak optimálisabban kezelhetővé, és a szélesebb körű gyógyszer-kombinációk, esetleg a gyógyszerek nagyobb adagokban történő alkalmazása növelhetné a RAASi-kezelés hatékonyságát. Ugyanakkor kérdéses, hogy annak ellenére, hogy a SeK-szintet normális tartományban tudjuk tartani, a vesefunkció jelentős csökkenése, vagy tünetes hipotenzió kialakulása nem fogja-e akadályozni az eddiginél intenzívebb kezeléseket. Kérdéses továbbá, hogy a hyperkalaemia veszélyének csökkentése önmagában elégséges lesz-e ahhoz, hogy a súlyosabban csökkent vesefunkciójú betegekre is ki lehessen terjeszteni a RAASi-k alkalmazását. Megnyugtató válaszok csak újabb, klinikai végpontú kontrollált tanulmányoktól várhatók.

\section{Következtetések}

A hyperkalaemia csökkent vesefunkciójú HFrEF-betegeknél gyakori jelenség. Hyperkalaemia és annak 
veszélye miatt a magas rizikójú betegek nem, vagy csak alacsonyabb arányban és adagban részesülnek RAASi-kezelésekben. A hyperkalaemia és a vele öszszefüggő kezelési korlátozások jelentősen növelhetik a szívelégtelen betegek halálozásának veszélyét. Az új típusú, a gyomor-bél rendszerben káliumot megkötő gyógyszerek, a patiromer és a nátrium-cirkónium-cikloszilikát alkalmazásától kielégítő tolerabilitás mellett kedvező hatás, a normális SeK-szint tartós fenntartása várható. Lehetővé tehetik a RAASi-kezelés optimális alkalmazását és kedvezően befolyásolhatják a szívelégtelenség hosszú távú kimenetelét. Ugyanakkor a napi klinikai gyakorlatba történő integrálásuk és a betegek gyógyszer adherenciájának elérése jelentős kihívást jelenthet.

\section{Irodalom}

1. Palmer BF. A physiologic-based approach to the evaluation of a patient with hyperkalemia. Am J Kidney Dis 2010; 56: 387-393. doi: https://doi.org/10.1053/j.ajkd.2010.01.020.

2. Ponikowski P, Voors A A, Anker SD, et al. 2016 ESC Guidelines for the diagnosis and treatment of acute and chronic heart failure: The Task Force for the diagnosis and treatment of acute and chronic heart failure of the European Society of Cardiology (ESC) Developed with the special contribution of the Heart Failure Association (HFA) of the ESC. Eur Heart J 2016; 37(27): 2129-2200 - https://doi. org/10.1093/eurheartj/ehw128

3. Sterns RH, Rojas $M$, Bernstein $P$, et al. lon-exchange resins for the treatment of hyperkalemia: are they safe and effective? J Am Soc Nephrol 2010; 21: 733-735. doi: https://doi.org/10.1681/ ASN.2010010079

4. Li L, Harrison SD, Cope MJ, et al. Mechanism of action and pharmacology of patiromer, a nonabsorbed cross-linked polymer that lowers serum potassium concentration in patients with hyperkalemia. J Cardiovasc Pharmacol Ther 2016; 21: 456-465. DOI: https://doi. org/10.1177/1074248416629549

5. Tamargo J, Caballero R, Delpon E, et al. New drugs for the treatment of hyperkalemia in patients treated with renin-angiotensin-aldosterone system inhibitors - hype or hope? Discov Med 2014; 18 249-254. PMID: 25425465

6. Aldahl M, Caroline A-S, Davidsen J L, et al. Associations of serum potassium levels with mortality in chronic heart failure patients. Eur Heart J 2017; 38: 2890-2896, https://doi.org/10.1093/eurheartj/ ehx460

7. Vardeny O, Claggett B, Anand I, et al. Incidence, predictors, and outcomes related to hypo- and hyperkalemia in patients with severe heart failure treated with a mineralocorticoid receptor antagonist. Circ Heart Fail 2014; 7: 573-9. PMID: 24812304 DOI: https://doi. org/10.1161/CIRCHEARTFAILURE.114.001104

8. The SOLVD investigators: Arbor A, Nicklas J M, Pitt B, et al. Effect of enalapril on survival in patients with reduced left ventricular ejection fractions and congestive heart failure. N Engl J Med 1991; 325: 293-302. DOI: https://doi.org/10.1056/NEJM199108013250501 9. Pitt B, Zannad F, Remme W J, et al. The effect of spironolactone on morbidity and mortality in patients with severe heart failure. Randomized Aldactone Evaluation study investigators. N Engl J Med 1999; 341: 709-17. DOI: https://doi.org/10.1056/NEJM199909023411001 10. Zannad F, McMurray JJ V, Krum H, et al. Eplerenone in patients with systolic heart failure and mild symptoms. N Engl J Med 2011; 364: 11-21. DOI: https://doi.org/10.1056/NEJMoa1009492

11. McMurray JJV, Packer M, Desai AS, et al. Angiotensin-neprilysin inhibition versus enalapril in heart failure. The PARADIGM-HF stu- dy. N Engl J Med 2014; 371: 993-1004. DOI: https://doi.org/10.1056/ NEJMoa1409077

12. Juurlink DN, Mamdani MM, Lee DS, et al. Rates of hyperkalemia after publication of the randomized Aldactone Evaluation study. N Engl J Med 2004; 351: 543-51. DOI: https://doi.org/10.1056/NEJMoa040135

13. Svensson M, Gustafsson F, Galatius S, et al. How prevalent is hyperkalemia and renal dysfunction during treatment with spironolactone in patients with congestive heart failure?

J Card Fail 2004; 10(4): 297-303. PMID: 15309695 DOI: https://doi. org/10.1016/j.cardfail.2003.10.012

14. Bozkurt B, Agoston I, Knowlton AA, et al. Complications of inappropriate use of spironolactone in heart failure: when an old medicine spirals out of new guidelines. J Am Coll Cardiol 2003; 41(2): $211-$ 4. PMID: 12535810 https://doi.org/10.1016/S0735-1097(02)02694-3. 15. Maggioni AP, Anker SD, Dahlström U, et al. Are hospitalized or ambulatory patients with heart failure treated in accordance with European Society of Cardiology guidelines? Evidence from 12,440 patients of the ESC Heart Failure Long-Term Registry. Eur J Heart Fail 2013; 15(10): 1173-84. doi: https://doi.org/10.1093/eurihf/hft134. Epub 2013 Aug 26.

16. Murray E, Reaven N L, Funk S E, et al. Evaluation of the Treatment Gap Between Clinical Guidelines and the Utilization of Renin-Angiotensin-Aldosterone System Inhibitors. Am J Manag Care 2015; 11: S212-20. PMID: 26619183

17. Komajda M, Cowie MR, Tavazzi L, et al. Physicians' guideline adherence is associated with better prognosis in outpatients with heart failure with reduced ejection fraction: the QUALIFY international registry. Eur J Heart Fail 2017; 19(11): 1414-1423. doi: https://doi. org/10.1002/ejhf.887. Epub 2017 Apr 30.

18. Ouwerkerk W, Voors AA, Anker SD, et al. Determinants and clinical outcome of uptitration of ACE-inhibitors and beta-blockers in patients with heart failure: a prospective European study. Eur Heart J 2017; 38(24): 1883-1890. doi: https://doi.org/10.1093/eurheartj/ $\underline{\mathrm{ehx} 026 .}$

19. Jain N, Kotla S, Little BB, et al. Predictors of hyperkalemia and death in patients with cardiac and renal disease. Am J Cardiol 2012; 109: 1510-3. doi: https://doi.org/10.1002/ejhf.300

20. Yancy CW, Jessup M, Bozkurt B, et al. 2017 ACC/AHA/HFSA Focused Update of the 2013 ACCF/AHA Guideline for the Management of Heart Failure. Circulation 2017; 000: e000-e000. DOI: https://doi.org/10.1161/CIR.0000000000000509

21. Ponikowski P, Voors A, Anker S D, et al. 2016 ESC Guidelines for the diagnosis and treatment of acute and chronic heart failure - Web Addenda The Task Force for the diagnosis and treatment of acute and chronic heart failure of the European Society of Cardiology (ESC) Developed with the special contribution of the Heart Failure Association (HFA) of the ESC. Eur Heart J 2016; https://doi. org/10.1093/eurheartj/ehw128

22. Ray K, Dorman S, Watson R, et al. Severe hyperkalemia due to the concomitant use of salt substitutes and ACE inhibitors in hypertension: a potentially life threatening interaction. J Hum Hypertens 1999; 13: 717-20. PMID: 10516744

23. Antoniou T, Gomes T, Mamdani MM, et al. Trimethoprim-sulfamethoxazole induced hyperkalemia in elderly patients receiving spironolactone: nested case-control study. BMJ 2011; 343: d5228. doi: https://doi.org/10.1136/bmj.d5228

24. Yancy CW, Jessup M, Bozkurt B, et al. 2013 ACCF/AHA guideline for the management of heart failure: a report of the American College of Cardiology Foundation/American Heart Association task force on practice guidelines. J Am Coll Cardiol 2013; 62: e147-239. PMID: 23741058, DOI: https://doi.org/10.1161/CIR.0b013e31829e8776

25. Perazella MA. Trimethoprim-induced hyperkalemia: clinical data, mechanism, prevention and management. Drug Saf 2000; 22 : 227-36. PMID: 10738846 
26. Sarwar CM,aPapadimitriu L, Pitt B, et al. Hyperkalemia in Heart Failure. J Am Coll Cardiol 2016; 68(14): 1575-89. doi: https://doi, org/10.1016/j.jacc.2016.06.060.

27. Desai AS, Vardeny O, Claggett B, et al. Reduced risk of hyperkalemia during treatment of heart failure with mineralocorticoid receptor antagonists by use of sacubitril/valsartan compared with enalapril: a secondary analysis of the PARADIGM-HF trial. JAMA Cardiol. 2017; 2(1): 79-85. doi: https://doi.org/10.1001/jamacardio.2016.4733.2016 28. Pitt B, Kober L, Ponikowski $P$, et al. Safety and tolerability of the novel non-steroidal mineralocorticoid receptor antagonist BAY 94-8862 in patients with chronic heart failure and mild or moderate chronic kidney disease: a randomized, double-blind trial. Eur Heart J 2013; 34: 2453-63. doi: https://doi.org/10.1093/eurheartj/eht187. Epub 2013 May 27.

29. Filippatos G, Anker S D, Böhm M, et al. A randomized controlled study of finerenone vs. eplerenone in patients with worsening chronic heart failure and diabetes mellitus and/or chronic kidney disease. Eur Heart J 2016; 37: 2105-14. doi: https://doi.org/10.1093/ eurhearti/ehw132. Epub 2016 Apr 29.

30. Pitt B, Anker SD, Bushinsky DA, et al. Evaluation of the efficacy and safety of RLY5016, a polymeric potassium binder, in a double-blind, placebo-controlled study in patients with chronic heart failure (the PEARL-HF) trial. Eur Heart J 2011; 32: 820-8. DOI: https:// doi.org/10.1093/eurheartj/eha502

31. Weir MR, Bakris GL, Bushinsky DA, et al. Patiromer in patients with kidney disease and hyperkalemia receiving RAAS inhibitors. N Engl J Med 2015; 372: 211-21. DOI: https://doi.org/10.1056/NEJMoa1410853
32. Bakris GL, Pitt B, Weir MR, et al. Effect of Patiromer on Serum Potassium Level in Patients With Hyperkalemia and Diabetic Kidney Disease: The AMETHYST-DN Randomized Clinical Trial. JAMA 2015 Jul 14; 314(2): 151-61. doi: https://doi.org/10.1001/ jama.2015.7446.

33. Lesko LJ, Offmann E, Brew CT, et al. Evaluation of the Potential for Drug Interactions With Patiromer in Healthy Volunteers. J Cardiovasc Pharmacol Ther 2017; 22(5): 434-446. doi: https://doi. org/10.1177/1074248417691135. Epub 2017 Feb 13

34. Weir M, Bakris G, Gross C, et al. Abstract P602: Patiromer decreased aldosterone, urine albumin/creatinine ratio, and blood pressure in patients with chronic kidney disease and hyperkalemia on RAAS inhibitors: results from OPAL-HK [abstract]. Hypertension 2015; 66: AP602. https://doi.org/10.1016/j.kint.2016.04.019

35. Packham DK, Henrik SR, et al. Sodium Zirconium Cyclosilicate in Hyperkalemia. N Engl J Med 2015; 372: 222-231. DOI: https://doi. org/10.1056/NEJMoa1411487

36. Kosiborod M, Rasmussen R, Lavin P, et al. Effect of Sodium Zirconium Cyclosilicate on Potassium Lowering for 28 Days Among Outpatients With Hyperkalemia The HARMONIZE Randomized Clinical Trial JAMA 2014; 312(21): 2223-2233. doi: https://doi. org/10.1001/jama.2014.15688

37. Anker SD, Kosiborod M, Zannad F, et al. Maintenance of serum potassium with sodium zirconium cyclosilicate (ZS-9) in heart failure patients: results from a phase 3 randomized, doubleblind, placebo-controlled trial. Eur J Heart Fail 2015; 17: 1050-6. DOI: https:/ doi.org/10.1002/ejhf.300

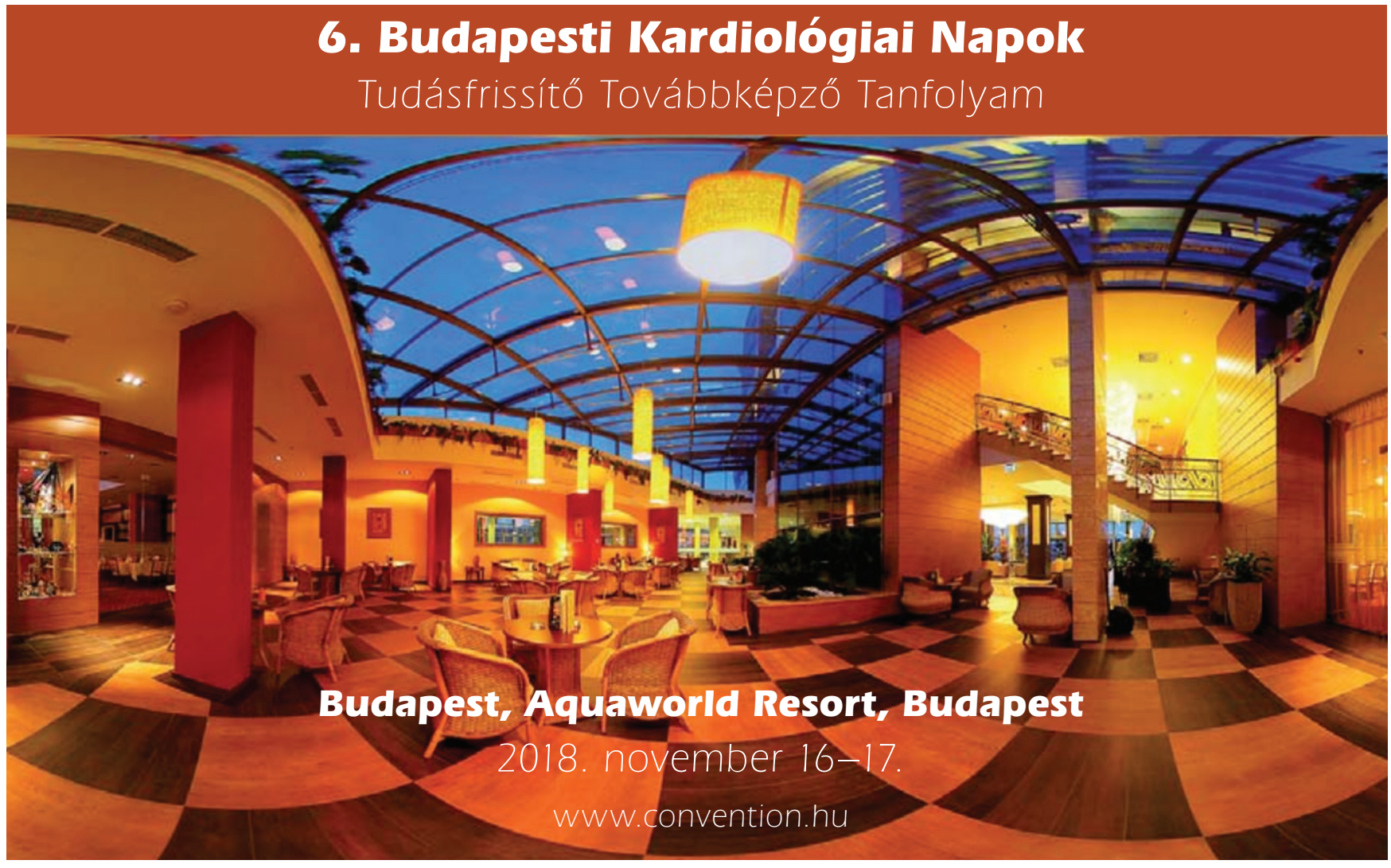

